\title{
A Review of Interconnected Minigrid Solution for Underserved Distribution Network in Nigeria
}

\author{
Akintunde K. Akinlabi $^{1}$ (D) Victor O. Oladokun ${ }^{1}$ \\ Received: 23 July 2020 / Accepted: 1 June 2021 / Published online: 26 June 2021 \\ (C) The Author(s), under exclusive licence to Springer Nature Singapore Pte Ltd. 2021
}

\begin{abstract}
The epileptic nature of electricity supply in Nigeria requires a pragmatic introduction of the interconnected minigrid system to increase the number of insufficient hours of supply to customers. This approach has not been widely adopted by the licensed electricity distribution companies and minigrid investors despite the economic potentials and efforts of Nigeria's Rural Electrification Agency in supporting the deployment. This paper follows the history of electricity in Nigeria to the current post-power sector reforms era, reviews the minigrid operations and business models that investors and stakeholders could adopt for the successful deployment of interconnected minigrid. It also showcases some viable commercially operated minigrids in selected locations in Nigeria. Conclusively, the paper made some recommendations for the successful deployment of interconnected minigrids for underserved distribution networks to augment gaps created by inadequate hours of supply.
\end{abstract}

Keywords Interconnected minigrid $\cdot$ Hours of supply $\cdot$ Electricity distribution companies $\cdot$ Minigrid investors $\cdot$ Underserved distribution network

\section{Introduction}

\section{History of Electricity in Nigeria}

Nigeria started generating electricity in the Lagos colony with two small generators in 1886 . A $60 \mathrm{~kW}$ generator was introduced to power Lagos in 1896, after fifteen years of electricity introduction in England (Niger Power Review [24]; Sambo et al. [40]; Onochie et al. [33]. The foremost utility company that started operations in 1929 was the Nigeria Electricity Supply Company (NESCO), with a hydroelectric power station located in Kurra, near Jos. In 1964, the Nigerian Government Electricity Undertaking (NGEU) was established as part of the Public Works Department, to oversee both liabilities and assets of electricity distribution in Lagos. An act of Parliament was enacted in 1951 to create the Electricity

Akintunde K. Akinlabi

tundelabi@yahoo.com

Victor O. Oladokun

vo.oladokun@mail1.ui.edu.ng

1 Department of Industrial and Production Engineering, University of Ibadan, Ibadan, Nigeria
Corporation of Nigeria (ECN). ECN was responsible for the integration of both privately-owned and government-owned power generating systems [5]. In February 1956, the Ijora power station was launched to increase accessibility and supply quality to Ikorodu, Shagamu, Ijebu-ode, and more cities in the Ibadan-Ijebu bloc leading to remarkable improvement in the economic activities in southwest states.

In 1962, another act of parliament was enacted to establish the Niger Dams Authority (NDA), and the first $132 \mathrm{KV}$ line was constructed to link Ijora generating plant to Ibadan generating plant. NDA was responsible for the development of hydroelectricity generation through the building and preservation of dams on the Niger River and beyond, improving navigation, supporting fish brine, and irrigation activities [22]. The renowned Kainji dam was constructed between 1962 and 1968. The Niger Power Review [25] stated that the combined contribution of defunct NDA and ECN led to the commencement of the operations of the national grid in 1966. The grid power transmission system linked Lagos with Kainji. The connection between Kaduna and Kainji was increased up to Kano and Zaria. In the same vein, the construction grid network of the Benin-Onitsha-Afam and Oshogbo-BeninUghelli was done in the Nigerian southern region. The NDA was the generating company while ECN was the distribution company selling electricity to customers. 
The National Electric Power Authority (NEPA) was established from the merger of NDA and ECN on the 1st of April 1972. The merger commenced with the appointment of the first manager for NEPA in January 1973. ECN was primarily in charge of sales and distribution and the NDA established to construct and operate transmission lines and power generating stations. The major reason for the merger is vesting authority for power production and distribution throughout Nigeria in one company that would also be accountable for the financial obligations. It will also lead to the useful utilization of resources available, financial, human, and other resources available in the industry across Nigeria. Okoro and Madueme [31] stated in their study that despite annual network expansion since the inception of NEPA, the electricity supply is not regular, and the current electricity connection access rate at 45\% [44]. Meanwhile, the federal government, between 1978 and 1983, established two committees to develop templates for restructuring NEPA into an efficient and autonomous entity in readiness for its unbundling and privatization. In 2005, NEPA was renamed as Power Holding Company of Nigeria $(\mathrm{PHCN})$ and takes responsibility for the entire power sector [38].

\section{Nigeria Power Sector Reform}

The Power Sector Reform Bill was signed into law in 2005 leading to unbundling of PHCN into six generating companies, one transmission company, and eleven distribution companies [32]. The unbundling is in readiness for privatization which was delayed due to change in government, policy inconsistency, administrative bureaucracy, and opposition by the labour union [33]. On November 1st, 2005, a regulatory body overseeing activities in the power sector including tariff regimes was inaugurated and named the Nigerian Electricity Regulatory Commission - NERC [30]. Other regulatory bodies created are the Nigeria Bulk Electricity Trading Plc (NBET) who oversees buying and selling power and provision of ancillary services for the successor generation companies and the independent power producers. The Rural Electrification Agency (REA) is to ensure the expansion of electricity to the unserved area, oversees the development, and uphold transparency in the sector [14].

In other to achieve the set objective of the Electric Power Sector Reform Act (EPSRA) 2005, a Presidential Action Committee on Power (PACP) was created to eliminate administrative constraints and ensure policy consistency among the key stakeholders. This led to the creation of the Presidential Task Force on Power (PTFP) to manage daily planning and activities for EPSRA [29]. The EPSRA objective is to develop the Nigeria Electricity Supply Industry (NESI) that would revolutionize and increase electricity footprint, support socio-economic and national development to meet the needs of Nigerians in the twenty-first century [9]. This will be accomplished by handing over NEPA's assets and liability to $\mathrm{PHCN}$ in preparation for unbundling into distribution, transmission, and generating entities. The Nigeria Electricity Liability Management Company (NELMCO) will also be established to take over the remaining PHCN assets and liabilities while the Nigeria Bulk Electricity Trading Company (NBET) will act as a negotiator between electricity generating and distribution companies. An independent regulatory body known as the Rural Electrification Agency (REA) will be saddled with the obligation of providing electricity to rural areas in Nigeria while the Nigeria Electricity Regulatory Commission (NERC) will be responsible for regulations of the electric power industry.

\section{Electricity Distribution in Nigeria}

One of the major outcomes of the reform in the power sector was the unbundling of PHCN into eleven distribution companies - DISCOs, one transmission company - TCN, and six generation companies - GENCOs. The Federal Government sold $80 \%$ and retain $20 \%$ of the GENCOs. The GENCOs are Afam, Egbin, Kainji, Sapele, Shiroro, and Ughelli. There are some Independent Power Producers (IPPs) which are connected to the grid under the auspices of the Niger Delta Power Holding Company (NDPHC), while other IPPs are still under construction. The Nigerian Electricity Supply Industry (NESI) currently has 23 grid-connected power generation stations in operation with a total installed capacity of 12,522 MW [44] and an available capacity of $6056 \mathrm{MW}$ as of 10th of May 2019. The peak energy is 109,372.01 MWH and the peak generation to date is 4602.4 MW [30]; [39]. The thermalbased plant is prevalent with an installed capacity of $10,142 \mathrm{MW}$ ( $81 \%$ of the total) and an available capacity of 4996 MW (83\% of the total). The total installed capacity of the three Hydropower generation stations is 1938 MW with an available capacity of $1060 \mathrm{MW}$. According to IEA, the Gas Thermal Plant with 64\%, Hydro with 23\%, and Steam Thermal Plant with $13 \%$ made up the total installed electricity generation in Nigeria.

The Federal Government still fully owned the Transmission Company of Nigeria (TCN) out of 18 successor companies unbundled from PHCN. The transmission asset was managed on a 4-year contract, on behalf of the government by Manitoba Hydro International (MHI Canada) whose responsibility is to revamp the network and wheel power from generating plants to distribution companies' infrastructure without system failure. MHI contract ended in August 2016 without achieving its objective and the government did not renew the contract. TCN is now being managed by the Federal Government and Nigerians. TCN has three operational departments: System Operations (SO), Transmission Service Provider (TSP), and Market Operations (MO). The System Operations is responsible for electricity flow from 
generation to distribution systems, system operations planning, grid reliability, dispatch, and control of electricity on the grid. The Transmission Service Provider oversees the maintenance and development of the transmission infrastructure. The Market Operations is responsible for the administration of the NESI market rules, overseeing the wholesale electricity market, and promoting efficiency [33].

TCN grid network has a total (theoretical) wheeling capacity of $7500 \mathrm{MW}$ across over 20,000 km transmission lines. The transmission system footprint does not cover every area of Nigeria [40]. A new generation and transmission peak of 5375 MW was achieved on Thursday 7th February 2019 at $2100 \mathrm{~h} \mathrm{[43].} \mathrm{There} \mathrm{are} \mathrm{acute} \mathrm{infrastructure} \mathrm{and} \mathrm{operational}$ challenges on the grid network. The network infrastructure is radial without redundancies consequently leading to an unreliable and technically weak grid with frequent failure due to major disturbances. The transmission losses on the network are approximately $7.4 \%$ which is higher than the $2-6 \%$ benchmark for emerging countries.

Nigeria has eleven electricity distribution companies (DISCOs). The Federal Government retains $40 \%$ and sold $60 \%$ to the private investor. The 11 DISCOs are in Abuja, Kaduna, Kano, Yola, Jos, Benin, Port-Harcourt, Enugu, Ibadan, Ikeja and Eko. After seven years of privatization, the electricity grid network is yet to be extended to many areas due to various challenges being face by the sector. However, the establishment of Minigrids systems harnessing different power generation sources to extend electricity supply to unserved areas will bridge the gap between electricity demand and supply [1,8]. This can be achieved by segmentation of such an area on the DISCO's network and serve them with a Minigrid solution (Table 1).

\section{Underserved Distribution Network}

The Nigeria Electricity Regulatory Commission described underserved distribution network areas as sections within DISCO's network with poor hours of supply or inefficient distribution networks [23]. This situation is known to the regulatory body as seen in many metropolitan areas in the country with only a few hours of electricity supply per day. This paper will review the underserved situation and propose the best approach to these common challenges with the interconnected Minigrid solution.

\section{MINIGRID System}

\section{Minigrid System}

Minigrid is a small and privately-owned system with up to $10 \mathrm{MW}$ (MW) generating capacity and distribution network that utilizes distributed electricity resources and controls power demand and supply to a cluster of customers [10, 12, 13, 21, 28]. Although, IEA [16] opined that there is no agreed-upon definition for Minigrid; it can also be defined as integrated electricity infrastructure, including energy from renewable sources such as solar and wind; inverters and batteries; monitoring, metering, and distribution system with interconnected users [17, 19]. The Nigeria Electricity Regulatory Commission (NERC) defined the Minigrids system as a power supply system with its electricity generation and distribution serving more than one customer" [23].

\section{Classification of Minigrid}

Minigrids can either be classified as isolated or interconnected. Isolated Minigrid is a localized generation and distribution of electricity to more than one customer that is not connected to the main grid. For Interconnected, it is an independent power generation and a distribution network installed within an existing grid and thereafter, connected to the grid network as part of the licensed electricity distribution network. The roles of stakeholders in the development of isolated and interconnected minigrid value chain in Nigeria is shown in Fig. 1.

After the Isolated minigrid operator signed an agreement with the host community, he will obtain an application for an exclusivity period from NERC and collect a building permit from REA based on the installed capacity of the minigrid. The operator of interconnected minigrid will enter into a tripartite agreement with the community and DISCO before proceeding with NERC approval processing. The tripartite contract termination must follow the terms and conditions in the contract will state the number of years of operations.

\section{Business Model}

Minigrids use a limited range of business models. The business model to adopt depends on the value chain dynamics

Table 1 Load Allocation for DISCOs. Source TCN (Oct. 2013)

\begin{tabular}{llllllllllll}
\hline $\mathrm{s} / \mathrm{n}$ & 1 & 2 & 3 & 4 & 5 & 6 & 7 & 8 & 9 & 10 & 11 \\
\hline DISCOs & Abuja & Benin & Eko & Enugu & Ibadan & Ikeja & Jos & Kaduna & Kano & Port Harcourt \\
\% Load Allocation & 11.5 & 9 & 11 & 9 & 13 & 15 & 5.5 & 8 & 8 & 6.5 & 11.5 \\
\hline
\end{tabular}




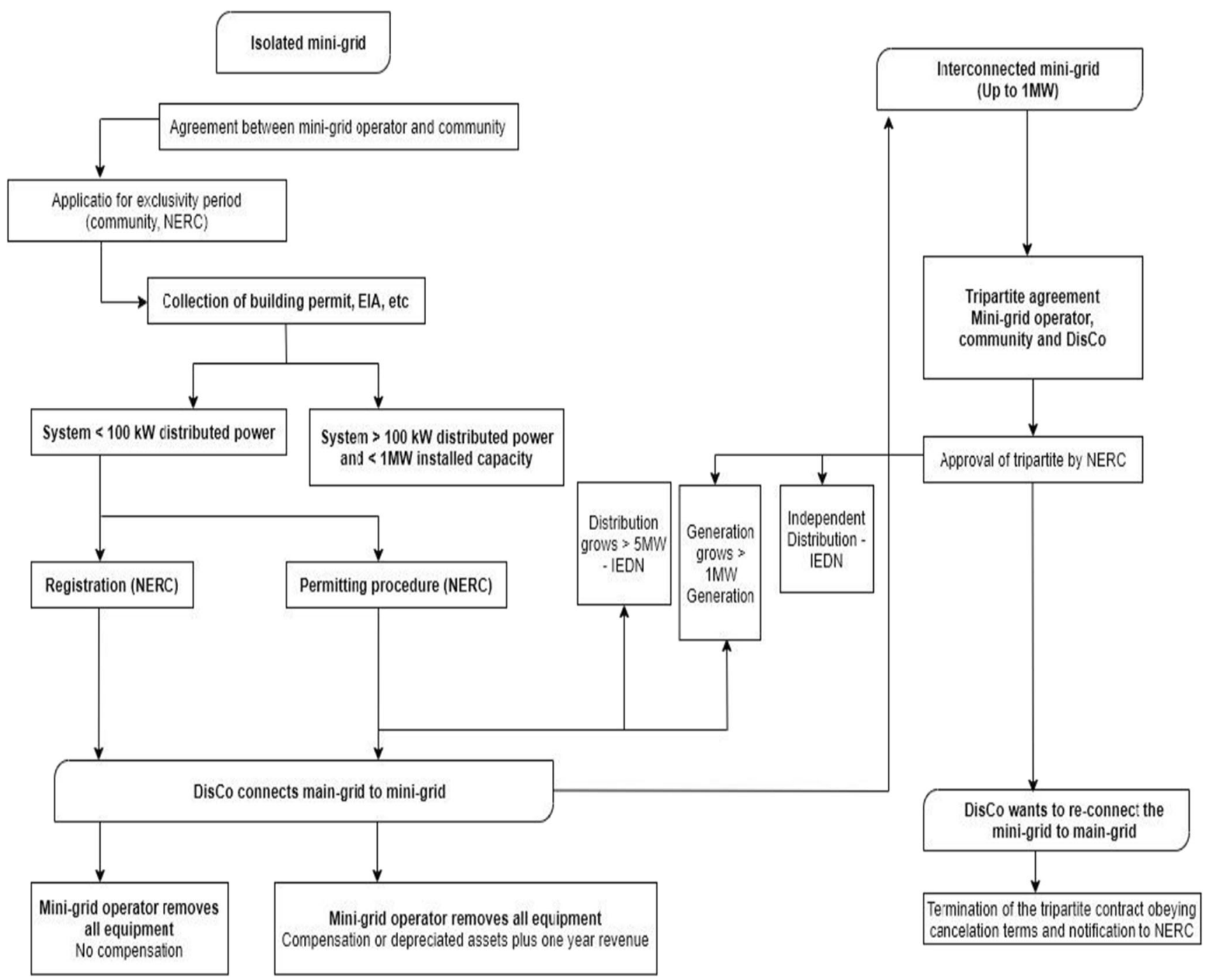

Fig. 1 Stakeholders' Roles in Minigrid Development in Nigeria. Source: International Renewable Energy Agency (2018)

such as location, technology, economic of scales, regulatory requirements, and stakeholders. Bhattacharyya and Palit [6] identified three broad business models as lighting only, lighting-plus, and anchor load as shown in Fig. 2. The lightingonly model provides each customer with microsystems of a few hundred watts of two LED lamp light points and a mobile charging point ensuring household demand of less than $10 \mathrm{~W}$. The lighting-plus model extends supply to other domestic equipment, small-scale industry, and community requirements based on payment affordability. The anchor-load model provides base demand to a major user and excess supply is provided for lighting requirements of the local community.

The Prepaid Metering system is widely adopted as commercial operations solutions by Minigrid operators in Nigeria with the following options (a) One-off connection fee with scratch cards for recharge (b) Pay-As-You-Go (PAYG) model with mobile phone top-up and (c) Cross- subsidizing residential customer tariff with commercial customers.

\section{Operations Model}

The main operational components of Minigrid are electricity generation and distribution. Safdar [36] opined that there are no gold-standard operation models, but it must be contextspecific and subject to regulatory, social-economics, geography, and environmental variables. Safdar [36] describes four main operation models for Minigrids as Utility operated, Private sector operated, Community operated, and Hybrid models combining the features of the other three models as shown in Fig. 3. The difference in the models worldwide is in their deployment and organization.

\section{Utility Operated}

This model is a concept where a government-owned utility company develops and manages Minigrids. Minigrid project is financed by the utility company with subsidies from 


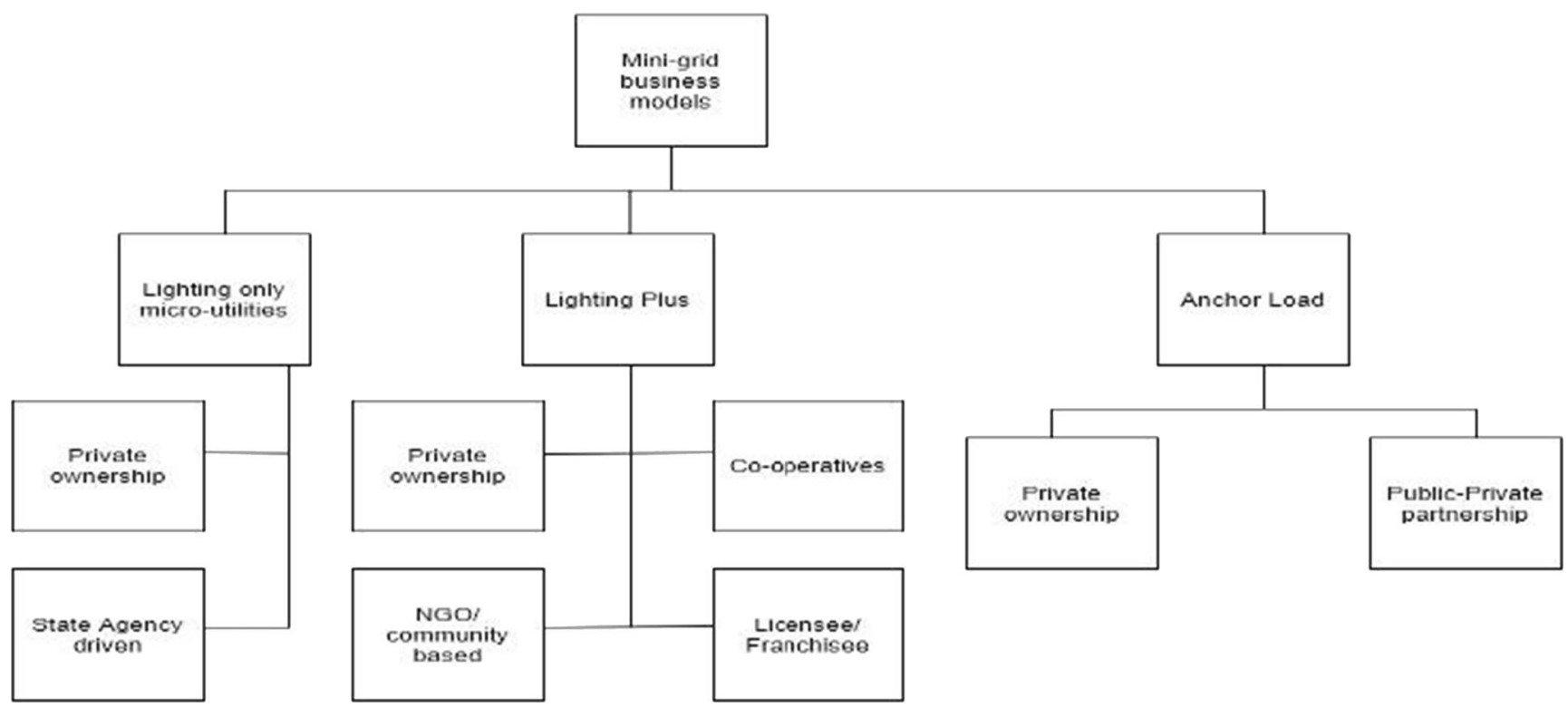

Fig. 2 Business Models for Minigrid based rural electrification. Source: Adapted from Bhattacharyya and Palit [6]

government and donor agencies [15]. The utility is responsible for the installation, operations, and maintenance as well as revenue collection from the customers connected to the Minigrid. Tariff charges of Minigrid customers may be the same or even lesser to main grid charges in which tariffs from maximum demand customers of the main grid may be used to cross-subsidize the tariff of Minigrid customers [12]. There is no single utility operated minigrid in Nigeria, However, in the year 2020, one of the eleven DISCOs in Nigeria, the Ibadan Electricity Distribution Company, partnered with two other companies and pioneered Nigeria's first rural commercial undergrid minigrid in Mokoliki, Ogun State [11]. Such collaboration with DISCOs to develop interconnected minigrid projects is still sparsely explored despite the vast market and opportunities.

\section{Private Sector Operated}

Minigrid project development, management, operations, and maintenance is the sole responsibility of the private sector. Capital can be raised from equity, loans, donor agencies, and government subsidies. There is growing attention on this model due to technological advancement, financial commitment from international donor agencies, and improved customer relationship management [18, 19]. According to Yadoo [46], private sector developers would require significant subsides and anchor load to run a successful enterprise. There are about 10 audited private-sector-driven commercial minigrid projects in Nigeria (Figs. 3 and 4). These projects are commercially viable with the implementation of costreflective tariffs. Customer satisfaction is high due to guaranteed and reliable supply with cost lesser than current

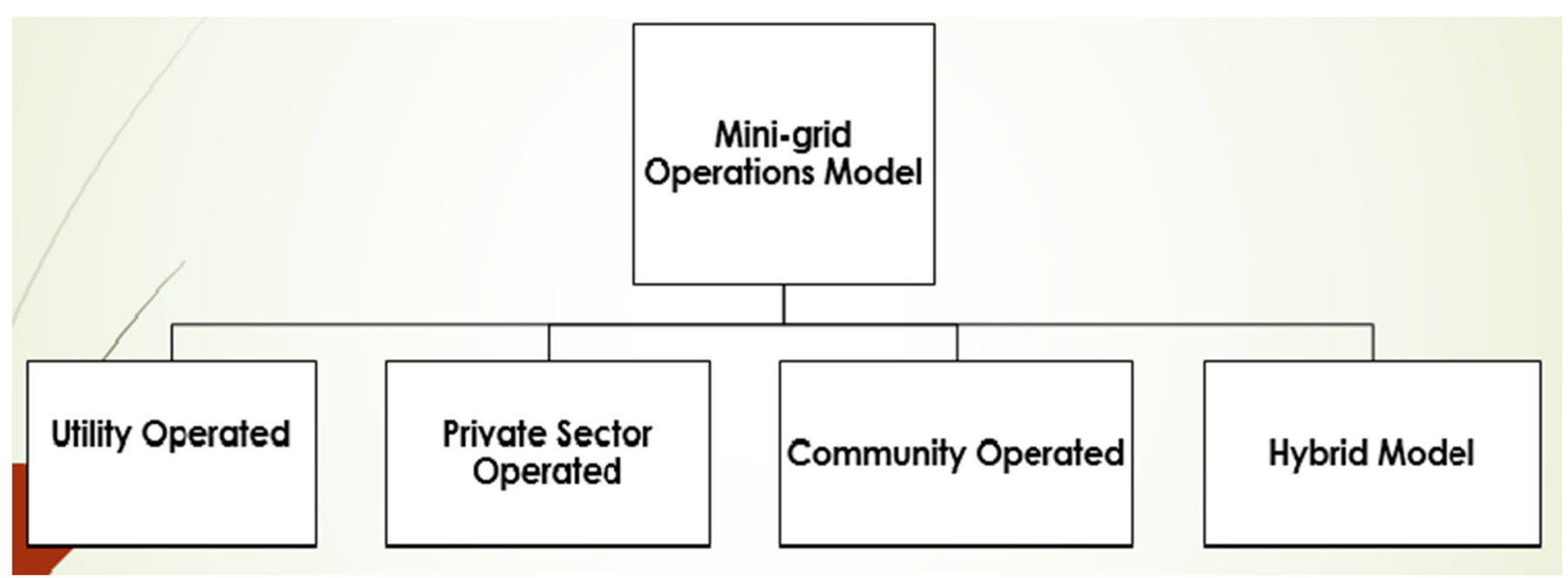

Fig. 3 Operations models for Minigrid 
Fig. 4 Audited Commercial Minigrids Sites in Nigeria. Source: RMI Nigeria Minigrid Investment Reports (2018)

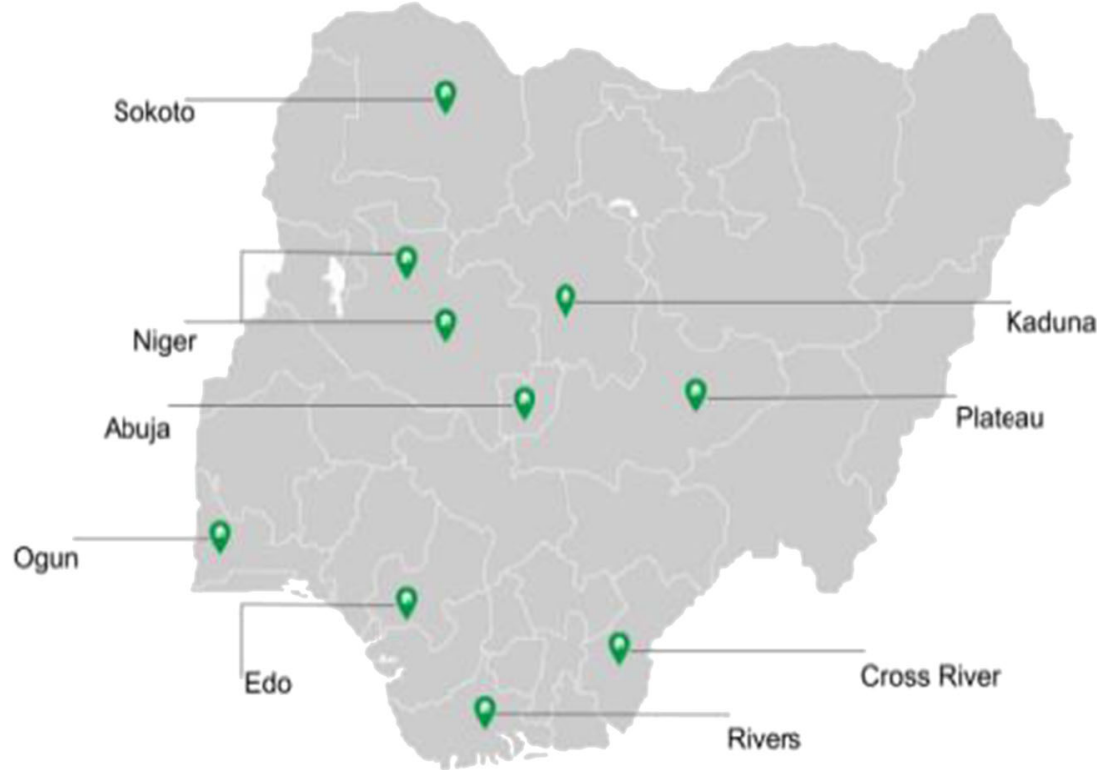

alternatives from petrol and diesel generators which were hitherto being used by the customers. Some of the successfully deployed and currently running minigrid project sites and their capacity are shown in Table 2.

\section{Community Operated}

The community formed a government-registered association to develop, operate, and manage the Minigrid. Donor agencies will provide a grant for the project while the community provides land, labour, and other resources in-kind [37]. Thirdparty expertise is required for the project planning, design, execution, and implementation as community members lack the technical know-how of Minigrid development. Yadoo [46] opined that the community-operated model could charge a lower tariff in some environments however the tariff should at least cover operations, maintenance, and depreciation costs

Table 2 Some Commercial Minigrids in Nigeria. Source: RMI Nigeria Minigrid Investment Reports (2018).

\begin{tabular}{lll}
\hline Minigrid Site & Capacity & Location \\
\hline Angwan Rina & $50 \mathrm{~kW}$ & Shendam LGA, Plateau State \\
Bisanti & $37 \mathrm{~kW}$ & Katcha LGA, Niger State \\
Dokan Karji & $16 \mathrm{~kW}$ & Kauru, Kaduna State \\
Egbeke & $10 \mathrm{~kW}$ & Etche LGA, River State \\
Gbamu Gbamu & $85 \mathrm{~kW}$ & Ijebu East LGA, Ogun State \\
Kigbe & $20 \mathrm{~kW}$ & Kwali LGA, Abuja FCT \\
Kurdula & $80 \mathrm{~kW}$ & Gudu LGA, Sokoto State \\
Obayantor & $40 \mathrm{~kW}$ & Ikpoba-Okha LGA, Edo State \\
Tunga Jika & $100 \mathrm{~kW}$ & Magama LGA, Niger State \\
Umon Island & $50 \mathrm{~kW}$ & Biase LGA, Cross River State \\
\hline
\end{tabular}

to ensure Minigrid sustainability. The scale of operations, availability of requisite technical know-how, and skills will determine the level of decision-making that will be localized in this model. This is very important to ensure the sustainability of Minigrids and prevent "boutique electrification" which suggests discontinuity of substantial electricity production as described by Tenenbaum et al. [42]. Nigeria's community has not harnessed this opportunity but the minigrid projects have found their ways into the communities through the Rural Electrification Agency projects like Solar Home System and Solar hybrid projects to a few selected higher educational institutions, markets, and communities.

\section{Hybrid Models}

This is a combination of different parts of the three other models above. Minigrid financing, ownership, and management are the responsibility of different bodies. Electricity generation and electricity distribution functions can be the responsibility of utility, private companies, or host communities. The transparency of property rights, contractual engagements, or joint venture arrangements for the model is guided by the regulatory framework. Some possible contractual arrangements of hybrid models are Power Purchase Agreements PPA [12], Public-Private Partnership - PPP, Concessions, and Renewable energy service companies. Nigeria's Rural Electrification Agency is currently leading the encouragement of communities and PPP development of Minigrid projects through several government incentives. There is a provision of capital subsidy to qualified PPP in their first year of operations through the REA's financial arm known as Rural Electrification Fund (REF) [41]. 


\section{Interconnected MINIGRID in Nigeria}

\section{Interconnected Minigrid Overview}

The central planning, building, and expansion of the main grid on a high voltage (HV) system is the responsibility of the Transmission Company of Nigeria TCN while Distribution Companies DISCOs are responsible for grid expansion in their franchise area. NERC [23] Regulations on minigrid allow licensed minigrid developers to choose a location while those applying for the license are restricted to unserved and underserved locations. According to the Minigrid investment report 2018, published by the Nigeria Economic Summit Group (NESG), the minigrid market in Nigeria is underdeveloped but massive with an annual revenue potential of US\$8 billion (N2.8 trillion). As the minigrid costs and alternatives energy sources are at the competitive stage, the market is at an inflection point and project funding is departing from grant funds to commercial investment. However, as the market is upscaling to more sites in the next three years, the minigrid costs will be reduced by more than half of the current cost [26].

Isolated Minigrids developers are qualified for the license in locations that is not under NERC's approved five-year expansion plan of DISCOs or allocated to another Independent Electricity Distribution Network. Interconnected Minigrids developers are qualified for the license in underserved locations within existing distribution networks but are currently having an unreliable and epileptic power supply. According to the World Bank and ESMAP [10] site visit report by Castalia, Minigrid developers in Nigeria are less concerned with assets compensation by the DISCOs. The developers usually choose locations that do not fall into DISCO's five-year expansion plan and not possible for main grid expansion before the financial payback period of between 10 and 15 years.

However, to bridge the identified supply gap within the underserved areas, the Rural Electrification Agency (REA) under the auspices of the Federal Ministry of Power recently launched the Interconnected Minigrid Acceleration Scheme (IMAS). The scheme is funded and supported by the European Union (EU) and the German government through the Nigeria Energy Support Programme (NESP) executed by Deutshe Gesellschaft fur Internationale Zusammenarbeit (GIZ). The objective of IMAS is to provide reliable electricity services at an affordable tariff to a minimum of 15,000 customers including residential, commercial, public, and productive users across Nigeria by September 2020. IMAS will run as privately-led solar interconnected minigrid projects [35].

IMAS is a nationwide non-site-specific open tender designed to select local Minigrid companies and support them with an inkind partial capital grant. The grant will be in the form of technical assistance, procured distribution, and metering equipment. Seven companies have been selected, as preferred bidders, as part of the Interconnected Minigrid Acceleration Scheme. Each developer is expected to choose an underserved site within the franchise area of the seven distribution companies. A bilateral agreement with DISCOs will be required and the developer would also sign an agreement with the identified community to be connected. In other to develop Minigrid in underserved areas such as locations with poor supply or non-functional distribution systems within a DISCO's area, a tripartite agreement with the DISCO and the community to be connected is required according to NERC [23] Regulations for Minigrids. Figure 3 shows the role of stakeholders in the deployment of Minigrids in Nigeria.

\section{Hybrid Interconnected Minigrid Solution}

A hybrid power system can be defined as a power generating system in which energy produced comprises a mix of more than one source of power-generating sources operating in a coordinated and independent manner (e.g. wind turbine, solar photovoltaic, and/or diesel generator). A hybrid interconnected Minigrid system is a localized hybrid electricity generation and distribution to customers that are connected to the grid supply [4]. It is an interconnected Minigrid solution with a hybrid power supply system specifically for underserved distribution areas. The concept of hybridizing interconnected Minigrid is to deliver dependable electricity supply due to the intermittent nature of renewable energy technologies which is mostly used for Minigrid. Renewable energy offers clean, sustainable, environmentally friendly with low maintenance and operating costs but there is a need to hybridize the power source due to the erratic nature of the resources since fluctuations in atmospheric situations [20].

\section{Distribution Network Segmentation}

The segmentation of the electricity distribution network is required for clear delineation of the segment of the underserved area to be serviced. This decision can be made employing consumer segmentation concepts adopting a set of criteria and analyzing their advantages and drawbacks [45]. The relevance of a segmentation process, as opined by Blattberg et al. [7], depends on the ability to separate consumers into homogeneous clusters that differ significantly in their characteristics like economic power and purchase behavior. It is strongly recommended for Minigrid investors to adopt a customer segmentation methodology in determining the section of underserved locations for distribution for successful project execution [34] [3].

\section{Some Deployment Factors}

There are other factors to be considered before the deployment of interconnected Minigrid in an underserved area. Some of 
these factors are site-selection decisions, regulatory requirements, technical and economic requirements, stakeholders' involvement, environmental impact analysis, and investment decision-making process [3]. An ideal site should be within an underserved network with less than $6 \mathrm{~h}$ of supply, sizeable customer population classified as residential, commercial, public, and anchor loads. Developers should abide by all regulatory requirements by government statutory authorities before the commencement of the project. These include but are not limited to registration, permit, license, tripartite agreements, cost-reflective tariff, business model - finite contract length, environmental laws, and regulations.

The techno-economic requirements include the existing distribution network segmentation, analysis of customers' energy demand to determine power generating technology to be used i.e. installed capacity, fuel type, rated power factor, reactive power capability. On the economic side, the distribution system value assessment will be done before making an investment decision on the Minigrid project. Other economic elements for consideration are the capital expenditure CAPEX, operating expense - OPEX, project life cycle, total revenues (Project Life), total expenses (Project Life), payback, and internal return rate - IRR, return on investment - ROI [2]. The investor should ensure that project viability evaluation is carefully carried out by ensuring connection fees to the Minigrid and tariff are appropriately set to guarantee revenue generation and quick return on investment.

The stakeholders involved in setting up an Interconnected Minigrid project are the developer, host community, distribution company, and the government regulatory agencies. The developer will identify a suitable site for minigrid and enter into tripartite discussion and legal agreement with the community and DISCO. Each stakeholder has their roles to play to ensure the successful implementation of the project. There should be an effective communication system among stakeholders to avoid any ambiguity before, during, and after the project. The environmental impact analysis of the project on the host community should be evaluated with a clearance certificate from regulatory agencies.

\section{Recommendation}

According to the review of the interconnected minigrid approach to solving the inadequate supply of electricity to underserved areas within the distribution network, this paper recommends that.

DISCOs should be encouraged to sign on new minigrid investors to bridge the supply gap from the main grid and provide more hours of supply to the underserved area. The current cost-reflective tariff by commercial operators should be sustained to attract more investors' participation and customers' acceptance. Investors should employ empirical data from electricity distribution companies in making site selection and investment decisions for their projects and ensure long term tripartite agreement is signed with DISCOs, investors, and customers within an interconnected Minigrid area to ensure the sustainability of the project.

For Policymakers, the Rural Electrification Agency should follow intentions and actions with execution for the fruitfulness of their noble innovations. NERC regulatory should be less cumbersome in the acquisition of a license for the establishment of interconnected Minigrid to encourage investors and developers while realistic timelines should be set for the integration of interconnected Minigrid as an embedded generation in the DISCOs' network. The distribution network should be re-designed for easy segmentation of underserved areas into clusters for the clear delineation for interconnected Minigrid projects. NERC and DISCOs should sensitize the customers in the underserved areas of imminent tariff review post-implementation of Minigrid.

\section{Conclusion}

This review is not all-encompassing as other factors are affecting the deployment of interconnected minigrid that the authors do not mention. However, if the recommendations herein are keenly adopted, there will be a remarkable increase in the deployment of interconnected minigrid by the licensed electricity distribution companies. This would greatly improve the hours of supply to many underserved areas, positively impact the socio-economic lives of the customers and boost the image of the DISCOs which has hitherto known for epileptic electricity supply.

\section{Declarations}

The authors declare that we have no known competing financial interests or personal relationships that could have appeared to influence the work reported in this paper.

Conflicts of Interest/Competing Interests The Authors declare that we have no conflict of interest or competing interests for this study.

\section{References}

1. Ainah PK, Folly KA (2015) Development of Micro-grid in SubSaharan Africa: an Overview. International Review of Electrical Engineering 10, N. 5 ISSN 1827- 6660 September - October 2015

2. Akinlabi, K. A, and Oladokun V.O. (2015). An empirical cost analysis of electricity from diesel powered electrical generator. International Journal of Engineering Innovation and Research 4(3): 428-432 ISSN: $2277-5668$

3. Akinlabi, K. A. and Oladokun V.O. (2020). Investment-based site selection model for interconnected mini-grid. Proceedings of the $5^{\text {th }}$ NA International Conference on Industrial Engineering and 
Operations Management Detroit, Michigan, USA, August 10-14, 2020

4. Arowolo W, Blechinger P, Caderb C, Perezd Y (2019) Seeking workable solutions to the electrification challenge in Nigeria: Minigrid, reverse auctions and institutional adaptation. Energy Strategy Reviews. An Elsevier journalRef 23(2019):114-141 www.elsevier.com/locate/esr. Accessed 16 Mar 2020

5. Awosope CA (2014) Nigeria Electricity Industry: Issues, Challenges, and Solutions.38th Covenant University Public Lecture Series. Vol. 3, No. 2, October 2014. https://www. covenantuniversity.edu.ng

6. Bhattacharyya SC, Palit D (2016) Minigrid based off-grid electrification to enhance electricity access in developing countries: What policies may be required? Energy Policy http://www.elsevier.com/ locate/enpol. Accessed 16 Mar 2020

7. Blattberg RC, Buesing T, Peacock P, Sen S (1978) Identifying the Deal-prone segment. J Mark Res 15(August):369-377

8. Boait P, Rupert G, Neal A, Davis G, Peter D (2017) ESCoBox: a set of tools for Minigrid sustainability in the developing world. Sustainability 2017(9):738 www.mdpi.com/journal/sustainability/. Accessed 8 Apr 2020

9. Energy Commission of Nigeria (ECN) (2014) Renewable Energy Master Plan, Abuja, Nigeria

10. Energy Sector Management Assistance Program - ESMAP (2017): Mini Grids in Nigeria: A Case Study of a Promising Market. Written by Castalia Strategic Advisor. November 2017 Conference Edition, Washington DC, Available at: https://www. esmap.org/. Accessed 8 Apr 2020

11. ESI AFRICA (2020). 'First Undergrid Minigrid Deployment in Nigeria a success. https://www.esi-africa.com/industry-sectors/ generation/solar/first-undergrid-mini-grid-deployment-in-nigeriaa-success/. Accessed 8 Apr 2020

12. Franz, Michael, Nico Peterschmidt, Michael Rohrer, Bozhil (2014): Minigrid policy toolkit: policy and business frameworks for successful Minigrids roll out, EUEI PDF: Eschborn, Available at: http://www.minigridpolicytoolkit.euei-pdf.org/. Accessed 8 Apr 2020

13. Greacen Chris, Engel Richard, Quetchenbach Thomas (2013): A guidebook on grid interconnection and islanded operation of Minigrid power systems up to $200 \mathrm{~kW}$. A publication of Lawrence Berkeley National Laboratory and Schatz Energy Research Center

14. Idemudia IG, Nordstrom DB (2016) Nigerian Power Sector: Opportunities and Challenges for Investment in 2016. Number 1930. Latham \& Watkins, Lagos, pp 1-15

15. IED (2013): Support study for DFID low carbon mini-grids: identifying the gaps and building the evidence base on low carbon Minigrids, Innovation Energie Développement: Francheville, Available at: https://www.gov.uk/dfid-research-outputs/ supportstudy-for-dfid-low-carbon-Minigrids-identifyingthe-gapsand-building-the-evidence-base-on-lowcarbon-Minigrids-finalreport. Accessed 25 May 2020

16. International Energy Agency (2011) "Design and operational recommendations on grid connection of PV hybrid mini-grids. IEA PVPS Task 11, Subtask 20, Activity 25," IEA-PVPS T11-06, Oct. 2011. http://www.iea-pvps-task11.org/HTMLobj-188/ Activity25-Publish.pdf. Accessed 25 May 2020

17. IRENA (2016) Innovation Outlook: Renewable minigrids, IRENA, Available at: http://www.irena.org/DocumentDownloads/ Publications/IRENA_Innovation_Outlook_Minigrids_Summary_ 2016.pdf. Accessed 25 May 2020

18. IRENA (2016b) Policies and regulations for private sector renewable energy Minigrids, IRENA, Available at: http://www.irena.org/ menu/index.aspx. International Renewable Energy Agency, Abu Dhabi, 2016
19. IRENA (2018): IRENA policies and regulations for renewable energy Minigrids. International renewable energy agency, November 2018. https://www.irena.org/

20. Jacobus $\mathrm{H}$ et al. (2011) Evaluating the impact of adding energy storage on the performance of a hybrid power system. Energy Conversation Management. 52: pp 2604-2610

21. Lilienthal, P. (2013) Hybrid renewable Minigrids: optimizing clean power everywhere. In Webinar

22. Manafa N (1995) Electricity development in Nigeria. Rasheen Publisher, Lagos, pp 37-51

23. Nigerian Electricity Regulatory Commission (2016), Regulation for mini-grids 2016 (Article 3) https://www.nerc.gov.ng

24. Niger Power Review (1985) Development of the Electricity Industry in Nigeria (1960-1985) 1-6

25. Niger Power Review (1989) Development of the Electricity Industry in Nigeria (1960-1989) 10-15

26. Nigerian Economic Summit Group (NESG) 2018. 'Minigrid Investment Report Scaling The Nigerian Market'. https://rmi.org/ wpcontent/uploads/2018/08/RMI_Nigeria_Minigrid_Investment Report 2018.pdf. Accessed 25 May 2020

27. Nigerian Electricity Regulatory Commission Minigrid Regulation, 2016. https://www.nerc.gov.ng

28. Nigerian Energy Support Programme - NESP (2017): Due Diligence Guidelines For Minigrid Investors In Nigeria. Published by Nigerian Energy Support Programme (NESP) and Deutsche Gesellschaft für Internationale Zusammenarbeit (GIZ) $\mathrm{GmbH}$

29. Nnaji B. (2011): Power sector outlook in Nigeria: Challenges, Constraints, and Opportunities. Conference proceedings at Nigerian Association for Energy Economics NAEE 4th Annual Conference, Abuja, Nigeria, 2011

30. Okafor, F. N. (2017). Improving Electric Power Sector Performance: The Role of Nigeria Electricity Regulatory Commission. Nigerian Academy of Engineering 2017 Public Lecture held on March 29, 2017, at University of Lagos, Akoka, Lagos, Nigeria, 1-14

31. Okoro OI, Madueme TC (2004) Solar energy Investments in a Developing Economy. Renew Energy 29:1599-1610

32. Omontuemhen P, Wijeratne D (2016) Powering Nigeria for the future (2016). The power sector in Nigeria report July 2016, $P w C$. https://www.pwc.com/gmc

33. Onochie UP, Egware HO, Eyakwanor TO (2015) The Nigeria Electric Power Sector (Opportunities and Challenges). Journal of Multidisciplinary Engineering Science and Technology (JMEST) ISSN: $3159-0040$ 2(4)

34. Oyedepo SO, Babalola OP, Nwanya SC, Kilanko O, Leramo RO, Aworinde AK, Adekeye T, Oyebanji JA, Abidakun AO, Agberegha OL (2018) Towards a Sustainable Electricity Supply in Nigeria: The Role of Decentralized Renewable Energy System. Eur J Sustain Dev Res 2(4):40. https://doi.org/10.20897/ejosdr/ 3908

35. REA, (2019). https://rea.gov.ng/call-proposal-interconnected-minigrid-acceleration-scheme/. Accessed 10 Jun 2020

36. Safdar Tayyab (2017): Business models for Minigrids. Technical Report 9. Smart Villages Initiatives. https://www.e4sv.org. Accessed 10 Jun 2020

37. Safdar T, Brian (2016) Energy and agriculture for smart villages in India, Technical Report 7, Smart Villages, Available at: http://e4sv. org/

38. Sambo A.S. (2008): Matching electricity supply with demand in Nigeria. International Association for Energy Economics. Fourth Quarter 2008. 32-36

39. Sambo AS (2018) Energy crisis in Nigeria: Engineers' proactive steps towards energy self-sufficiency. Lecture as the first in the series of the distinguished lectures in honour of Engr. Dr. E. J. S. 
Uujamhan, at the University of Benin, Benin City, on the 6th Day of April, 2018, 1-27

40. Sambo AS, Garba B, Zarma IH, Gaji MM (2010) Electricity generation and the present challenges in the Nigerian power sector. Energy Commission of Nigeria, Abuja

41. SE4ALL Africa Hub and African Development Bank (2018). 'Mini-grid market opportunity assessment: Nigeria'. Green MiniGrid Market Development Programme: SE4ALL Africa Hub \& African Development Bank

42. Tenenbaum B, Greacen C, Siyambalapitiya T, Knuckles J (2014) From the bottom up how small power producers and Minigrids can deliver electrification and renewable energy in Africa. World Bank, Washington DC

43. Transmission Company of Nigeria (2019): Transmission Company of Nigeria. https://www.tcnorg.com. Accessed 10 Jun 2020
44. USAID (2019): NIGERIA - Power Africa Fact Sheet. https://www. usaid.gov/powerafrica/nigeria. Accessed 14 Jun 2020

45. Wind Y (1978) Issues and advances in segmentation research. J Mark Res 15(August):317-337

46. Yadoo, Annabel (2012): Delivery Models for Decentralised Rural Electrification: Case studies in Nepal, Peru, and Kenya, International Institute for Environment and Development (iied), Available at: http://pubs.iied.org/pdfs/16032IIED.pdf. Accessed 14 Jun 2020

Publisher's Note Springer Nature remains neutral with regard to jurisdictional claims in published maps and institutional affiliations. 